Межерицкая Светлана Игоревна кандидат фбллологических наук доцент, фбакультет свободных искусств и наук, Санкт-Петербургский государственный университет. Россия, 199034, Санкт-Петербург, Университетская наб., 6 Тел.: +7 (812) 320-07-26 E-mail:mezh@mail.ru

\title{
RHETORIC IN THE SERVICE OF POLITICS: PANEGYRIC AND ITS ROLE IN THE ERA of The Second Sophistic
}

Аннотация. Расцвет ораторского искусства на востоке Римской империи на протяжении II-III вв. н. э. принято называть Второй софистикой - по аналогии с софистическим движением в Греции, главным образом в Афинах, в V в. до н. э. Появившиеся тогда в большом количестве «учителя мудрости» сумели сделать риторику важнейшим инструментом политического воздействия на жизнь государства и общества в целом. Союз политики и риторики, государственной власти и свободы творчества привели к совершенно неожиданным и колоссальным по своему значению результатам: к расцвету афинской демократии, с одной стороны, и к появлению шедевров в области словесного и художественного творчества, с другой. Речи таких выдающихся ораторов, как Исократ, Демосфен и др. оказывали огромное воздействие на общественное мнение и политику государства. В Римской империи, главным образом в городах Малой Азии, где испокон веков преобладало греческое культурное влияние, наступление «золотого века Антонинов» с его хорошо продуманной системой администрации на местах и расширением гражданских прав и свобод населения также способствовало значительному культурному подъему в обществе. Это нашло выражение прежде всего в появлении огромного числа ораторов и риторов - софистов, которые путешествовали из города в город, давая сеансы публичных декламаций или читая лекции по риторике. Софристы выступали с речами на самые разнообразные темы, наиболее же выдающимся из них нередко предоставлялось почетное право произнести торжественную речь на общегородском празднестве или сказать приветственное слово по случаю прибытия в город представителей римской власти и даже самого императора. Характерным примером могут служить две сохранившиеся до нас «смирнские» речи Элия Аристида, слава которого обеспечила этому оратору прочное место в ряду классиков позднего греческого красноречия. Обе речи адресованы 
римским официальным лицам и хорошо демонстрируют существование тесных культурно-политических связей между римской властью и греческой интеллектуальной элитой во II в. н. э., упрочившихся, по всей видимости, в результате неоднократных поездок императоров на Восток. Это дает нам основание рассматривать последнее как политическую подоплеку так называемого френомена Второй софистики.

Ключевые слова: риторика, древнегреческое ораторское искусство, Вторая софистика, эпидейктическое красноречие, приветственные речи, Элий Аристид

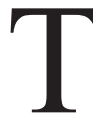
he tradition of welcoming orations, that is, speeches in honor of rulers arriving from afar, goes back to ancient times, as reflected in ancient Greek literature. Thus, in Aeschylus (Agam. 774), Agamemnon, who arrives in Argos, is welcomed by the choir coryphaeus and his wife Clytemnestra. From Athenaeus (VI 253c) we know that the Athenians likewise welcomed Demetrius Poliorcetes, greeting him with "hymns and choruses". However, this one and other known examples of the greetings of ruling persons are closely related to the poetic form. But it is not known just when the custom of welcoming arriving rulers with orations became firmly established. For the Roman era, the earliest historically attested occasion came during Germanicus's visit to Athens, whom, according to Tacitus, "the Greeks received $\langle. .$.$\rangle with the most exalted honors, continuously extolling the$ deeds and words of their ancestors, thereby giving a greater price to their flattery" (see: Annals II.53.3). There is no doubt that we are dealing here with an oration on the occasion of the arrival of the ruler.

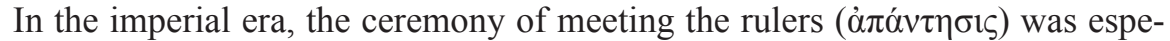
cially important and usually took place on a grand scale (in particular, see: [Grandior 1934: 182; MacCormack 1976: 43-45; 1981: 17-22, 65; Halfmann 1986: 112 ff.; Millar 1989: 29]). A solemn cortege was sent to meet the emperor or the official arriving in the city (usually the proconsul of the province). In their honor hymns were sung and speeches were delivered, and sometimes even statues were erected (see: Dio Chrys. XXXI 75, 112). The orations of this genre that have come down to us, as well as the rhetorical literature devoted to them, show that the utterance of solemn speeches in honor of arriving high-ranking guests was a frequent practice in the $2^{\text {nd }}-3^{\text {rd }}$ centuries A.D.

Ancient Greek rhetorical theory acquaints us with a rather complex and ramified system of genres, which can be conditionally combined under the name of "welcoming" orations. This one included orations of various kinds, depending on their purpose, place and circumstances of the utterance, personality of the speaker, etc. Thus, a speech specially written on the occasion of the arrival of the ruler and pronounced, apparently, outside the city walls, when the entire population came out

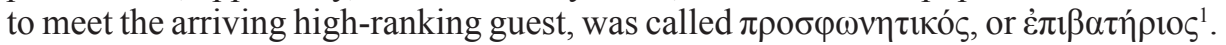
When the newcomer entered the city with a magnificent escort, a special speech literature.

${ }^{1}$ Before Menander of Laodicea ( $3^{\text {rd }}$ century A.D.), this term is not attested in rhetorical 


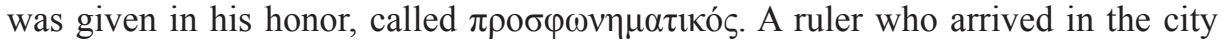
by sea was usually met in the city harbor. In this case, the speech was also called

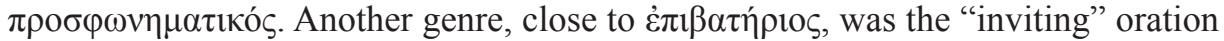
or invitation ( $\kappa \lambda \eta \tau 1 \kappa o ́ \varsigma)^{2}$. The latter could be addressed as to a god, in order that he manifests his presence, so also to the ruler, in order that he visits the city. Along with the speeches delivered on the occasion of the visit, there were also speeches on

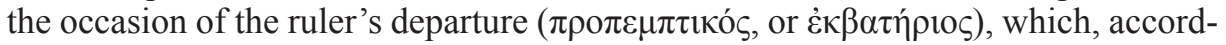
ingly, performed the function of the parting words ${ }^{3}$.

Let us consider in detail one of the aforementioned genres, namely, $\pi \rho \circ \sigma \varphi \omega-$

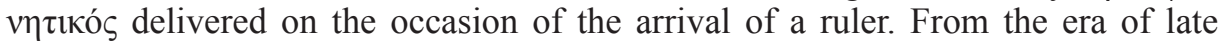
antiquity, we have both detailed rhetorical recommendations on the compilation of such speeches, and the actual speeches of this genre - in particular, the so-called "Smyrnean Orations" of Aelius Aristides ( $2^{\text {nd }}$ century), a major orator and one of the main representatives of the Second Sophistic (about him see: [Boulanger 1923; Wilamowitz-Möllendorff 1925: 333-345; Behr 1968]). First, let us turn to rhetorical theory to better understand the main features of the genre of welcoming oration. The famous $3^{\text {rd }}$ century rhetorician, Menander of Laodicea, in his treatise "On Epi-

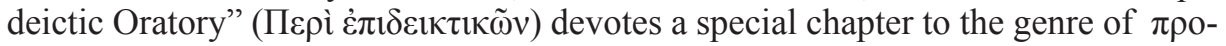

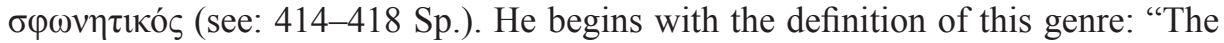
welcoming oration is a praise ( $\varepsilon \hat{v}(\eta \mu \rho \varsigma)$, pronounced by someone in the address of

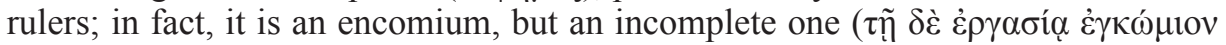

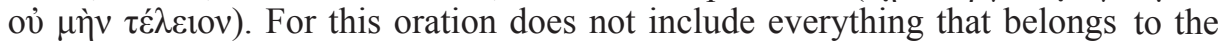
encomium, but is actually a welcoming" (415 Sp.). Further, Menander explains his

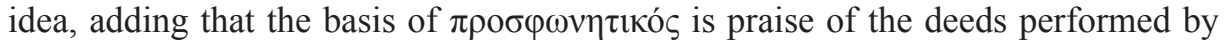
the addressee of the speech, and this is only one of the traditional elements of the encomium, whose rhetorical canon consists of a number of other topoi: praise for the clan and the ancestors of the addressee, praise for his upbringing and education, praise for his deeds, etc. In addition, the speech of praise usually began and ended with a prayer to the gods (see: [Burgess 1902: 87-263; Crusius 1905: 2581-2583; Payr 1962: 332-343; Pernot 1986: 33-53; 1993: 144-177]).

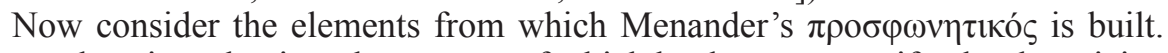
After a short introduction, the essence of which he does not specify, the rhetorician advises immediately to pass to the praise of the emperor, paying the main attention to his state activities and military victories. In doing so, he warns the speaker against

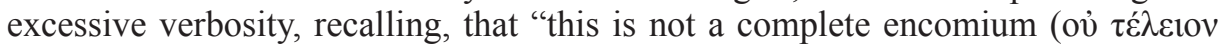

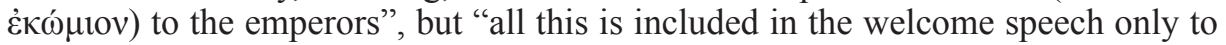
enhance the praise of the ruler" (415 Sp.). Then Menander advises to go directly to the praise of the person being greeted. At the same time, the obvious link between the two objects of praise is the idea that, strictly speaking, all the merits of the addressee in the civil service, which are to be listed in detail and praised further, are a consequence of the wise leadership and the reasonable choice of the emperor

${ }^{2}$ The only surviving historical example of this genre is the "Latin Panegyric", inviting Emperor Constantine to visit Augustodon, the birthplace of the author of the speech.

${ }^{3}$ A typical example of this kind is the oration of Aelius Aristides "To those who criticize him

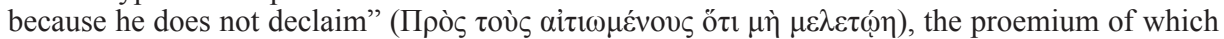
contains a short speech by the speaker to his friend, going on a long journey. Another example is the ninth "Florida" of Apuleius. 
who entrusted this person with the execution of the corresponding official duties. The praise of deeds, according to Menander, should be distributed according to the four kinds of virtue: wisdom, justice, prudence and courage. Further on, examples of deeds for each kind of virtue are given. Again, for the third time, there is a reminder that the genre in question is an "incomplete encomium", and in this connection - advice not to dwell too long on enumerating the virtues and the deeds: "For the welcome speech only touches the topoi of the encomium (o $\pi \rho \circ \sigma \varphi \omega v \eta \tau 1 \kappa o ̀ s$

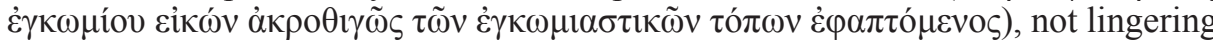
on them, as in complete encomia, unless someone wants to make a welcome speech in full accordance with the content of "encomium"' (416-417 Sp.). His arguments and recommendations are accompanied by numerous examples. Here is one of them, which is praise for the addressee of the speech: "There were plenty of rulers, beautiful both externally and internally, some in Asia and others in Europe, who deserved praise and have all the virtues, but there was no one better than you, for you surpassed them all" (417 Sp.). In the final part of the speech, according to Menander, there can be praise for the city, in which the speech is delivered, but the rhetorician notes the optional nature of such praise: "...this must not always be done, but at will” (Ibid.). The welcoming oration should end with a traditional prayer, characteristic for almost all epideictic genres - for the health and welfare of the emperor, the addressee of the speech and the city in which it is pronounced.

Given the above, it may be seen that praise is the basis of the genre $\pi \rho \circ \sigma \varphi \omega$ $\vee \eta \tau \imath \kappa o ́ s$, as in the case of encomium, but unlike the latter, it is not retrospective, but focuses mainly on the present: on the activities of the addressee of the speech for the benefit of the city, the state and the entire Roman people. There is no doubt

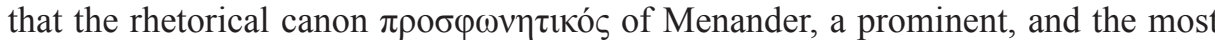
authoritative theoretician of his epoch, was compiled on the basis of extensive rhetorical practice, to which belonged not only the works of ancient Greek orators, contemporary to the rhetorician, but also a huge layer of the preceding literature including those relating to the so-called Second Sophistic. However, not a single speech has come down to us that would correspond exactly to the given description. On the other hand, the ancient Greek rhetorical tradition does not always provide exhaustive material: for example, it bypasses the genre of a welcoming oration to the emperor (probably very rare). Nevertheless, we know about the existence of such speeches, and some of them, for exemple, "The Welcome Speech to Julian" of Libanius (Or. XIII), even survived to our time. From this follows only one thing: both traditions - rhetorical theory as well as oratorical practice - should not be viewed in isolation, but rather in close connection with each other, since only in this way we can come to a more or less complete understanding of the essence and specifics of the eloquence of late antiquity.

As previously mentioned, in the literature of the Second Sophistic the genre of

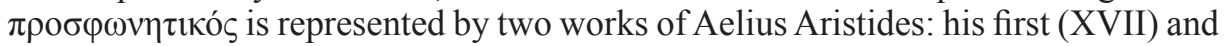
second (XXI) "Smyrnean Orations". The first, the name of which is supplemented in the manuscript tradition by the later postscript "political" ( $\Sigma \mu v \rho v \alpha \iota \kappa o ̀ \varsigma \pi 0 \lambda \imath \tau 1 \kappa o ́ \varsigma)$, is addressed to a certain unidentified Roman official. Several hypotheses regarding the probable addressee were proposed. According to A. Boulanger [Boulanger 1923: 384-385], the first "Smyrnean Oration" was addressed to Marcus Aurelius, who stayed in Egypt during the winter of 175/176 and then intended to go through 
Asia Minor to Athens. He considers this oration (which, given these circumstances, is to be qualified not as $\pi \rho 0 \sigma \varphi \omega v \eta \tau 1 \kappa o ́ \varsigma$ but rather as $\kappa \lambda \eta \tau \imath \kappa o ́ \varsigma)$ as an invitation to visit Smyrna, sent to the emperor on behalf of Smyrna's citizens. Thus, the composition of this oration, according to Boulanger, dates back to 176 A.D., when Marcus Aurelius did in fact visit Smyrna. In support of his hypothesis, Boulanger relied on a passage in Philostratus' "Biographies" (II, 9, 582-583), which states that, upon the arrival of the emperor in the city, Aristides avoided the emperor's court for a few days. This fact really cannot but cause bewilderment, given the high status and wide popularity of Aristides as the first orator of Smyrna. According to Boulanger, this could have happened only if the oration in question had been already sent to the emperor earlier. In turn, the latter circumstance explains well the fact why this oration does not contain praise for the ruling person, mandatory in case it was pronounced in his presence. In support of his hypothesis, Boulanger also refers to a passage in

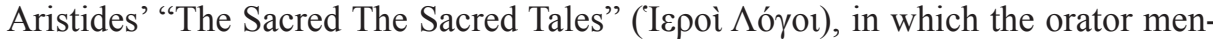
tions his message to the emperor, who was staying at that time in Syria (see: XLVII, 33-34K). However, as C. Behr correctly observes [Behr 1968: 109], there is an obvious anachronism in the last argument of Boulanger, since Aristides' first "Sacred Tale" had been written five years before the "Smyrnean Oration" allegedly inviting the emperor to visit the city. Consequently, we cannot identify the message to the emperor mentioned in the "Sacred Tales" with the "Smyrnean Oration". However, it could not be addressed to Marcus Aurelius, especially since in this oration there is nothing pointing to the high status of its addressee. So, we have no reason to link the "Smyrnean Oration" with the Emperor's visit to Smyrna in 176 A.D. As for other possible addressees of the speech, some scholars also suggested Lucius Verus and a certain Roman proconsul who had just taken office, supposedly Publius Cluvius Maximus Paulinus (see: [Rohde 1886: 188; Behr 1968: 91]). In this case, the oration should be dated back to, respectively, 166 or 157 A.D. The latest assumption was put forward by C. Behr on the grounds that the second of the two "Smyrnean Orations" is addressed, as is known, to the son of the addressee of the first one - apparently also to the proconsul of Asia, who visited Smyrna for the second time many years later, as mentioned in the text of this speech (XXI, 7). Probably, during his first visit to Smyrna, the so-called Paulinus' son accompanied his father as a legate, which is quite possible. The custom of taking children on official trips in order to prepare them for future activities in the civil service was widely practiced by Roman officials. Thus, according to Behr, the first "Smyrnean Oration" was pronounced by Aristides in public on the occasion of the arrival of the proconsul of Asia to Smyrna to participate in the Dionysia, as well as for the trials that took place in the city in early spring. The second "Smyrnean Oration", which has the title $\Sigma \mu v \rho v \alpha$ icòs

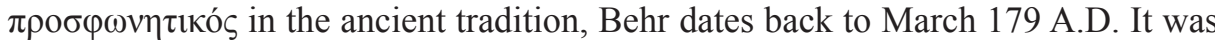
written on the occasion of the arrival of another Roman proconsul in Smyrna - the son of the addressee of the first oration - for all the same proceedings, as already mentioned. However, unlike the previous one, Aristides no longer gave this oration personally (due to poor health, as discussed in the introduction, § 1-2), but sent it to the Roman proconsul directly from his estate in Mysia, where the orator was permanently living his last years until his death in 180/181 A.D.

If we accept Behr's hypothesis, which as a whole is persuasive, we must admit

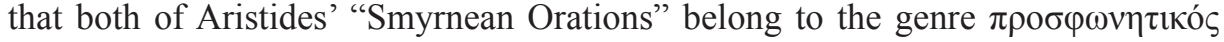


representing welcome speeches in honor of the arriving ruler. However, on closer examination, it turns out that both in form and content they are typical panegyrics for the city. Thus, the first "Smyrnean Oration" (XVII) begins with a short introduction $(\S 1)$, in which, in the traditional panegyric manner, the difficulty of the task for the speaker is justified - to celebrate worthily the city of Smyrna. In the main part of the oration Aristides also follows the generally accepted scheme of panegyric: it is praise for the ancient origin of Smyrna, its legendary and historical past ( $\$ 3-6)$. However, in contrast to the classical panegyrics, he considers these topics more briefly. In addition, from all the abundance of mythological and historical material, Aristides chooses only one episode, which he dwells on in detail, since it has a direct bearing on the circumstances of the oration: these are the yearly Dionysia celebrated in Smyrna. It seems highly desirable to the orator that his addressee would take part in them. Then a detailed description of Smyrna and all its attractions follows: the Acropolis, the temples, the palaestras, the thermae, the porticoes etc. (§9-11). In this part it is very reminiscent of a guide offering the ruler a virtual route through the city - the same that, in all likelihood, was to be accomplished in reality. For us, this is truly a unique description of ancient Smyrna, composed by an eyewitness (see also: [Bürchner 1927: 757-758]). Along with the sights of the city, its magnificent surroundings are praised, as well as the nature and climate of this region $(\S 12,14-17,19,21-22)$. In the final part of the speech $(\S 23)$, instead of the usual prayer, there is an appeal to the addressee, in which Aristides expresses a hope for the successful completion of his important mission (it should be recalled that this is a court session, which was the main goal of the proconsul's arrival). According to tradition, he also complains about his oratorical impotence in front of such a majestic subject of speech.

The structure of the second "Smyrnean Oration" (XXI) repeats in many respects the structure of the previous one. Thus, a short introduction $(\S 1-2)$, containing a characteristic topos for panegyric, i. e. an excuse for having the boldness to deliver a speech, is followed by a list of myths associated with the founding of Smyrna (§ 3-4) (even more concise than in the preceding oration) and of the sights of the city $(\S 5)$. Aristides explains his brevity pointing out that he had already described all this in the first "Smyrnean Oration", which in this part really does coincide with the one in question. However, the further part of the oration represents a sharp and unexpected transition to modernity, with the main theme being chosen shortly before the earthquake that had severely destroyed the city, and the subsequent rapid restoration of Smyrna ( $(7-11)$. The latter, as stressed by Aristides, is the merit of the emperor himself, which gives the speaker also an occasion to briefly praise the rulers of Rome. Let us cite this passage in full, since the oration corresponds in this aspect to the rhetorical canon of Menander: "...For the founders of the city, who rule all the cities, have not been surpassed neither in the philanthropy nor in revealed deeds; only they alone were able to make Smyrna even better than it had been before" $(\$ 12)$. The oration ends with a brief appeal to the ruler and the addressee, which, in some implicit form, includes praise necessary in such a case: "Everyone, perhaps, will consider it a good omen - that you come to our city, and that by your stay in Smyrna you close the circle, exactly repeating the previous official trip of your father. For this is a great success for the city. May luck be with you in everything!" ( $\$ 16)$. 
Thus, the welcoming orations of Aristides do not follow consistently, if at all, the rules developed by the ancient Greek rhetorical theory for the genre $\pi \rho о \sigma \varphi \omega-$

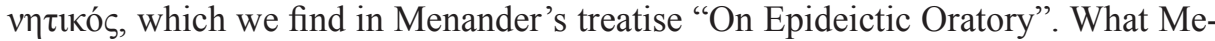
nander proclaims to be an optional topos for the welcome oration, namely, praise for the city, becomes the main content in both orations of Aristides. On the other hand, the main theme for $\pi \rho 0 \sigma \varphi \omega v \eta \tau$ เós — praise for the ruler and the emperor alongside their deeds - hardly finds an expression in these orations, except for a brief appeal to the former and a brief mention of the benefactions of the latter in the second oration. In their structure, both welcoming orations of Aristides are much closer to another genre of epideictic oratory - namely, the encomium of the city rather than to the actual genre $\pi \rho 0 \sigma \varphi \omega v \eta \tau$ ฯó $\varsigma$ itself. The explanation for this can be seen, first of all, in the fact that the existence of a rhetorical canon both for this and for other genres of epideictic eloquence did not requirement the speaker to follow the canon strictly and unswervingly in everything. Although the orators were limited to a certain framework of the existing genre tradition, they nevertheless enjoyed sufficient freedom in the choice and layout of the material. The set of topoi within the traditional structure of such orations could vary depending on the circumstances of the declamation or the writing of the oration, the goals and tasks that the speaker set for him, the political status of the addressee, etc. At the same time, the orator could exclude some topoi, expand another one or cut short a third one at his discretion. The higher the professional level and the talent of the orator, the greater the individuality of his style and the greater the deviation from the generally accepted canon that could be expected from him.

In addition, it is worth noting that throughout all antiquity Aristides enjoyed a well-deserved fame as an unequaled panegyrist (see: [Oliver 1953; 1968; Day 1980; Klein 1981] etc.), and, perhaps, it was he who adapted the classical encomium to a person to new and urgent problems of his era. Among his extensive oratorical heritage we find panegyrics to cities, temples and even the sea. In the era of the Second Sophistic, the panegyric becomes an almost universal genre, which, in particular, attests to the important role played by the oratorical art in the cultural and political life of the empire.

\section{Литература}

Behr 1968 - Behr C. A. Aelius Aristides and The Sacred Tales. Amsterdam: A. M. Hakkert, 1968.

Boulanger 1923 - Boulanger A. Aelius Aristides et la sophistique dans la province d'Asie au IIe siècle de notre ère. Paris: De Boccard, 1923.

Bürchner 1927 - Bürchner L. Smyrna // Paulys Realencyclopädie der classischen Altertumswissenschaft. Bd. III A. Stuttgart: Metzler, 1927. Sp. 730-764.

Burgess 1902 - Burgess T. C. Epideictic literature // University of Chicago Studies in classical philology. Vol. 3. 1902. P. 87-263.

Crusius 1905 - Crusius O. Enkomion // Paulys Realencyclopädie der classischen Altertumswissenschaft. Bd. V. Stuttgart: Metzler, 1905. Sp. 2581-2583.

Day 1980 - Day J. W. The glory of Athens. The popular tradition as reflected in the Panathenaicus of Aelius Aristides. Chicago: Are, 1980. 
Graindor 1934 - Graindor P. Athénes sous Hadrien. Le Caire: Imprimerie Nationale; Boulac, 1934.

Halfmann 1986 - Halfmann H. Itinera principum. Geschichte und Typologie der Kaiserreisen im römischen Reich. Stuttgart: Steiner, 1986 (Heidelberger althistorische Beiträge und epigraphische Studien; Bd. 2).

Klein 1981 - Klein R. (1981). Die Romrede des Aelius Aristides. Darmstadt: WBG, 1981.

Millar 1989 - Millar F. The emperor in the Roman world. London: Bristol Classical Press, 1989.

MacCormack 1976 - MacCormack S. G. Latin prose panegyrics: Tradition and discontinuity in the Later Roman Empire // Revue des Études Augustiniennes. Vol. 22. 1976. P. 29-77.

MacCormack 1981 - MacCormack S. G. Art and ceremony in Late Antiquity. Berkeley: Univ. of California Press, 1981.

Oliver 1953 - Oliver J. H. The ruling power. A study of the Roman Empire in the second century after Christ through the Roman Oration of Aelius Aristides. Philadelphia: American Philosophical Society, 1953 (TAPhS, new ser., vol. 43, pt. 4).

Oliver 1968 - Oliver J. $H$. The civilizing power. A study of the Panathenaic discourse of Aelius Aristides against the background of literature and cultural conflict, with text, translation and commentary. Philadelphia: American Philosophical Society, 1968 (TAPhS, new ser., vol. 58, pt. 1).

Payr 1962 - Payr T. Enkomion // Reallexicon für Antike und Christentum. Bd. 5. 1962. Sp. $332-343$.

Pernot 1982 - Pernot L. Les topoi de l'éloge chez Ménandros le Rhéteur // Revue des Études Grecques. Vol. 99. 1982. P. 33-53. (In French).

Pernot 1992 - Pernot L. La rhétorique de l'èloge dans le monde gréco-romain: 2 vols. Paris: Institut d'études augustiniennes, 1992 (Collection des études augustiniennes. Série Antiquité; 137-138).

Rohde 1886 - Rohde E. Die asianische Rhetorik und zweite Sophistik // Rheinisches Museum für Philologie. Neue Folge. Bd. 41. 1886. S. 170-190.

Wilamowitz-Möllendorff 1925 - Wilamowitz-Möllendorff U. von. Der Rhetor Aristides // Sitzungsberichte der Preussischen Akademie der Wissenschaften. Bd. 28. Fasc. 5. S. 333-353.

\title{
RHETORIC IN THE SERVICE OF POLITICS: PANEGYRIC AND ITS ROLE IN THE ERA OF THE SECOND SOpHISTIC
}

\author{
Mezheritskaya, Svetlana I. \\ PhD (Candidate of Science in Philology) \\ Associate Professor, St. Petersburg State University \\ Russia, 199034, St. Petersburg, Universitetskaya emb., 6 \\ Tel.: +7 (812) 320-07-26 \\ E-mail:mezh@mail.ru
}

Abstract. The flourishing of oratory in the East of the Roman Empire during the 2nd-3rd centuries A.D. is usually called the Second Sophistic - by analogy with the sophistical movement in Greece, mainly in Athens, in the $5^{\text {th }}$ century B.C. The "teachers of wisdom" managed then to make rhetoric the most important instrument of political influence on the life of the state and the society as a whole. The union of politics and rhetoric, state power and freedom of expression led to results that were completely unexpected 
and colossal in their significance: the flourishing of Athenian democracy, on the one hand, and the emergence of masterpieces in the field of verbal creativity, on the other. The speeches of such outstanding orators as Isocrates, Demosthenes, and others had a tremendous impact on public opinion and state policy. In the Roman Empire, mainly in the cities of Asia Minor, where Greek cultural influence predominated from time immemorial, the approach of the so-called "golden age of the Antonines" with its well-designed system of administration in the provinces and the extension of civil rights and freedoms of the population also contributed to a significant cultural rise in society. This was reflected, firstly, in the appearance of a huge number of speakers and rhetoricians sophists who traveled from city to city giving public recitations or reading lectures on rhetoric. Sophists made speeches on a variety of topics, and the most prominent of them were often granted the honorable right to deliver a solemn speech at a citywide celebration or a welcoming speech on the occasion of the arrival in the city of representatives of the Roman authorities and even the emperor himself. A typical example involves the two surviving "Smyrnean orations" by Aelius Aristides: their fame secured this orator a solid place among the classics of late Greek eloquence. Both speeches are addressed to Roman officials and demonstrate well the close cultural and political ties between the Roman authorities and the Greek intellectual elite in the $2^{\text {nd }}$ century A.D., strengthened, apparently, thanks to repeated trips of emperors to the East. This gives us reason to view the latter as the political underpinning of the so-called "phenomenon" of the Second Sophistic.

Keywords: Rhetoric, old Greek oratory, Second Sophistic, epideictic eloquence, "welcoming" speeches, Aelius Aristides

\section{References}

Behr, C. A. (1968). Aelius Aristides and The Sacred Tales. Amsterdam: A. M. Hakkert.

Boulanger, A. (1923). Aelius Aristides et la sophistique dans la province d'Asie au Ile siècle de notre ère. Paris: De Boccard. (In French).

Bürchner, L. (1927). Smyrna. In Paulys Realencyclopädie der classischen Altertumswissenschaft. (Vol. III A), cols. 730-764. Stuttgart: Metzler. (In German).

Burgess, T. C. (1902). Epideictic literature. University of Chicago Studies in classical philology (Vol. 3), 87-263.

Crusius, O. (1905). Enkomion. In Paulys Realencyclopädie der classischen Altertumswissenschaft. (Vol. V), cols. 2581-2583. Stuttgart: Metzler. (In German).

Day, J. W. (1980). The glory of Athens. The popular tradition as reflected in the Panathenaicus of Aelius Aristides. Chicago: Ares.

Graindor, P. (1934). Athénes sous Hadrien. Le Caire: Imprimerie Nationale; Boulac. (In French).

Halfmann, H. (1986). Itinera principum. Geschichte und Typologie der Kaiserreisen im römischen Reich. Stuttgart: Steiner. (Heidelberger althistorische Beiträge und epigraphische Studien, Vol. 2). (In German). 
Klein, R. (1981). Die Romrede des Aelius Aristides. Darmstadt: WBG. (In German).

Millar, F. (1989). The emperor in the Roman world. London: Bristol Classical Press.

MacCormack, S. G. (1976). Latin prose panegyrics: Tradition and discontinuity in the Later Roman Empire. Revue des Études Augustiniennes, 22, 29-77.

MacCormack, S. G. (1981). Art and ceremony in Late Antiquity. Berkeley: Univ. of California Press.

Oliver, J. H. (1953). The ruling power. A study of the Roman Empire in the second century after Christ through the Roman Oration of Aelius Aristides. Philadelphia: American Philosophical Society. (TAPhS, new ser., v. 43, pt. 4).

Oliver, J. H. (1968). The civilizing power. A study of the Panathenaic discourse of Aelius Aristides against the background of literature and cultural conflict, with text, translation and commentary. Philadelphia: American Philosophical Society. (TAPhS, new ser., v. 58, pt. 1).

Payr, T. (1962). Enkomion. In Reallexicon für Antike und Christentum (Vol. 5), cols. 332-343. (In German).

Pernot, L. (1986). Les topoi de l'éloge chez Ménandros le Rhéteur. Revue des Études Grecques, 99, 33-53. (In French).

Pernot, L. (1993). La rhétorique de l'èloge dans le monde gréco-romain. (2 vols.). Paris: Institut d'études augustiniennes. (Collection des études augustiniennes. Série Antiquité, 137-138). (In French).

Rohde, E. (1886). Die asianische Rhetorik und zweite Sophistik. Rheinisches Museum für Philologie, Neue Folge, 41, 170-190. (In German).

Wilamowitz-Möllendorff, U. von. (1925). Der Rhetor Aristides. Sitzungsberichte der Preussischen Akademie der Wissenschaften, 28(5), 333-353. (In German).

To cite this article:

Mezheritskaya, S. I. (2017). Rhetoric in the Service of POlitics: PANegyric And its role in the era of the Second Sophistic. Shagi / Steps, 3(4), 224-233. 